\title{
New findings on submerged patch reefs and reefal carbonate rocks at water depths of 70-100 m on the insular shelf off Miyako-jima, southern Ryukyus, Japan
}

\author{
Takahiko Inoue* (1) and Kohsaku Arai
}

\begin{abstract}
Sub-bottom profiling (SBP) surveys and bathymetric mapping conducted off the shore of Miyako-jima, which belongs to the southern Ryukyus in the Ryukyu Island Arc, have revealed the presence of mound-shaped structures 3-8 $\mathrm{m}$ high and 50-120 $\mathrm{m}$ wide at depths of 70-100 $\mathrm{m}$. The SBP surveys showed that the mounds possess strong distinct, convex upward reflector shapes at the top, which we interpret as submerged reefs and reefal sediments. Additionally, modern stratified sediment layers that cover these mound-shaped structures indicate that those reefs began forming and advancing shoreward in a back-stepping fashion as a result of sea-level rise. An analysis of the mound distribution shown by SBP and multibeam echo sounding (MBES) surveys suggest that they might have been formed during the lowstand stage of sea-level change, which includes the Last Glacial Period, because the distribution of these mounds is limited to water depths of 70 to $100 \mathrm{~m}$, deeper than where present-day reefs grow. The SBP images hint that such high-resolution seismic profiles, accompanied by detailed bathymetric mapping off the reefal area, have the potential to provide effective indicators of not only coral reef paleoenvironment development, but also the tectonic setting of this offshore area.
\end{abstract}

Keywords: Sub-bottom profiling (SBP), Bathymetric mapping, Ryukyu Island Arc, Sea-level change, Submerged reef, Miyako-jima, Northwestern Pacific

\section{Introduction}

The Ryukyu Island Arc extends $1200 \mathrm{~km}$ from Kyushu to Taiwan along the Ryukyu Trench where the Philippine Sea Plate is subducting beneath the Eurasian Plate. Miyako-jima belongs to the southern Ryukyus in the Ryukyu Island Arc and is located approximately $100 \mathrm{~km}$ east-northeast of Ishigaki-jima (Fig. 1). This island, about $30 \mathrm{~km}$ long, is triangle-shaped and surrounded by the small islands of O-gami-jima, Ikema-jima, Irabu-jima, Shimoji-shima, and Kurima-jima. Modern coral reefs are widely distributed around the islands. This study focuses on the area off the northeastern coast of Miyako-jima.

\footnotetext{
* Correspondence: inoue-taku@aist.go.jp

The Research Institute of Geology and Geoinformation, Geological Survey of Japan, AIST, Tsukuba Central 7 AIST, 1-1-1 Higashi, Tsukuba, Ibaraki, Japan
}

Off the central part of the northeastern coast lies Tsufutsuwa Reef (Tsufutsuwa Bise), a $2.5 \mathrm{~km}$ long patch reef (Coral Reefs of Japan 2004). Toward the northern end of this coast, there is a group of patch reefs around Ikemajima and O-gami-jima. The Yaebishi Reefs, developed north of Ikema-jima as shown in Fig. 2, consist of approximately 100 table and platform reefs scattered in the offshore area.

Numerous studies have examined the morphology of modern coral reefs in the Ryukyu Islands (e.g., Hori 1977; Hori and Kayanne 2000). Hori (1977) and Hori and Kayanne (2000) examined and summarized the topographic features of the reef slope to the island shelf as well as the coral reef itself. Hori and Kayanne (2000) reported that in the central to southern Ryukyus, the 


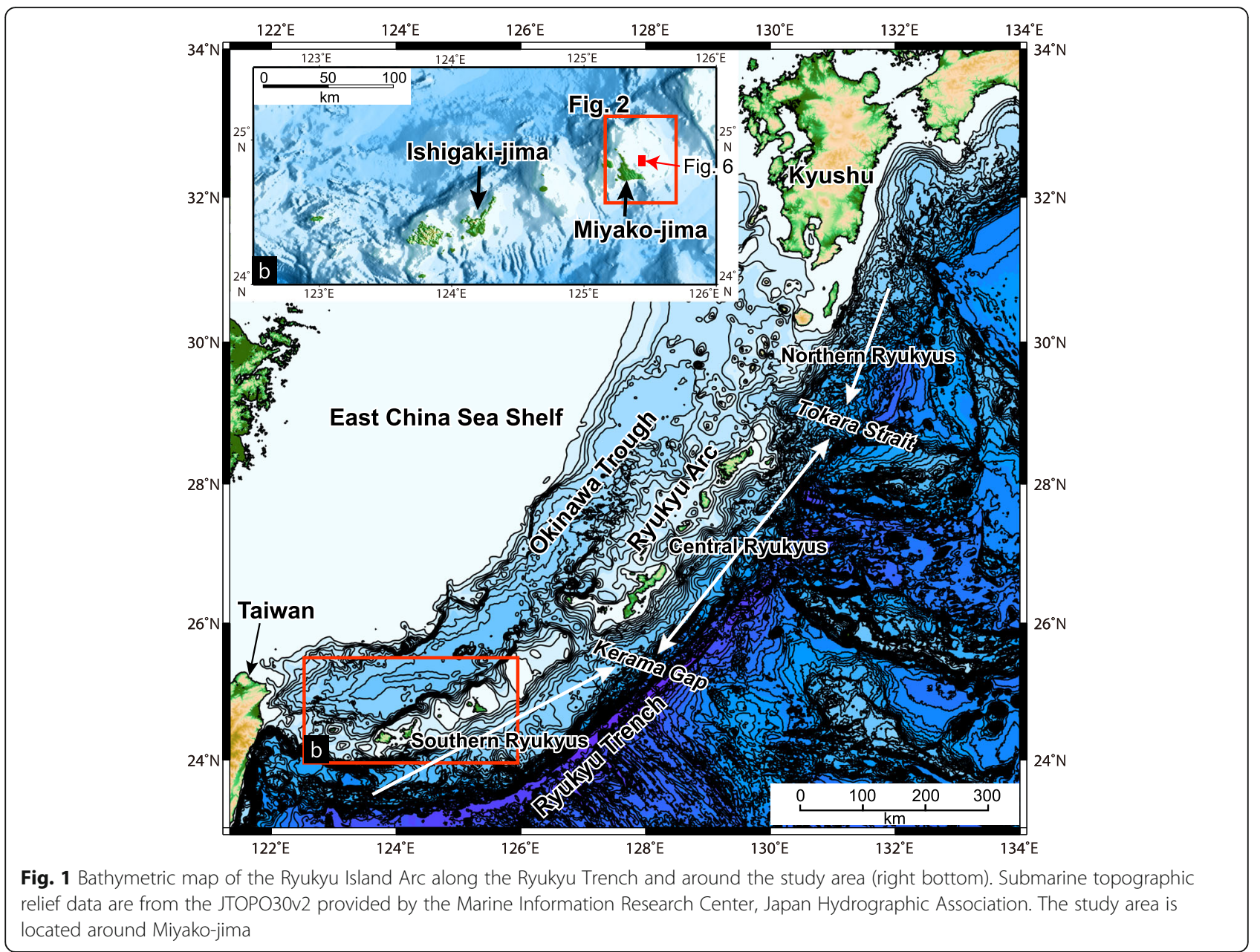

distinctive morphological features of the island shelf were classified as the inner break, outer break, inner shelf, and shelf break in descending order, and distinctive coral reef topographic features are not found below the inner break (i.e., water depths greater than 50-55 $\mathrm{m}$; Fig. 3). However, submerged coral reefs have been discovered on continental shelves and on island margins in many tropical and subtropical areas worldwide (e.g., Khanna et al. 2017; Rovere et al. 2018; Webster et al. 2004). Other reports have shown that sea-level rises since the Last Glacial Maximum have been non-linear (Fairbanks 1989) and that reef back-stepping and reef drowning can be seen as indicators of rapid sea-level rise (e.g., Blanchon and Shaw 1995).

Currently, paleo water depth interpretation and radiometric dating of fossil reef organisms are used to constrain the amplitude and timing of sea-level changes (e.g., Bard et al. 1996). Indeed, investigations off Barbados (Peltier and Fairbanks 2006), Hawaii (Webster et al. 2004), Papua New Guinea (Edwards et al. 1993), Tahiti (Camoin et al. 2006; Deschamps et al. 2012), the Great Barrier Reef (Webster et al. 2018; Yokoyama et al.
2018), the Scott Reef (Collins et al. 2011), and the Maldives (Fürstenau et al. 2010) have confirmed the significance of these reefs as unique archives of postglacial global sea-level rises.

Although the presence of coral reefs in the Ryukyu Island Arc during glacial periods has not previously been considered, submerged reefs located near the northern limit of the coral reefs 15-30 kyr old have been reported off Irabu-jima below the seafloor at a water depth of $118 \mathrm{~m}$ (Sasaki et al. 2006). Further, topographical studies have pointed out the existence of submerged reefs on the Miyako-Sone platform (water depth, $56 \mathrm{~m}$; Arai et al. 2016), off Okinawa-jima (water depth, $140 \mathrm{~m}$; Arai et al. 2012), and off Amami-o-shima and Kikai-jima (water depth, $110 \mathrm{~m}$; Matsuda et al. 2011). Around Miyakojima, modern reefs have developed only in water depths shallower than $60 \mathrm{~m}$ according to Obata and Tsuji (1992), and drowned reefs from the Last Glacial Maximum have been found along the isobath around $125 \mathrm{~m}$ (Obata and Tsuji 1992; Sasaki et al. 2006). Herein, we report on reef-like structures in this barren zone from 70 to $100 \mathrm{~m}$ deep in the central and southern Ryukyus 


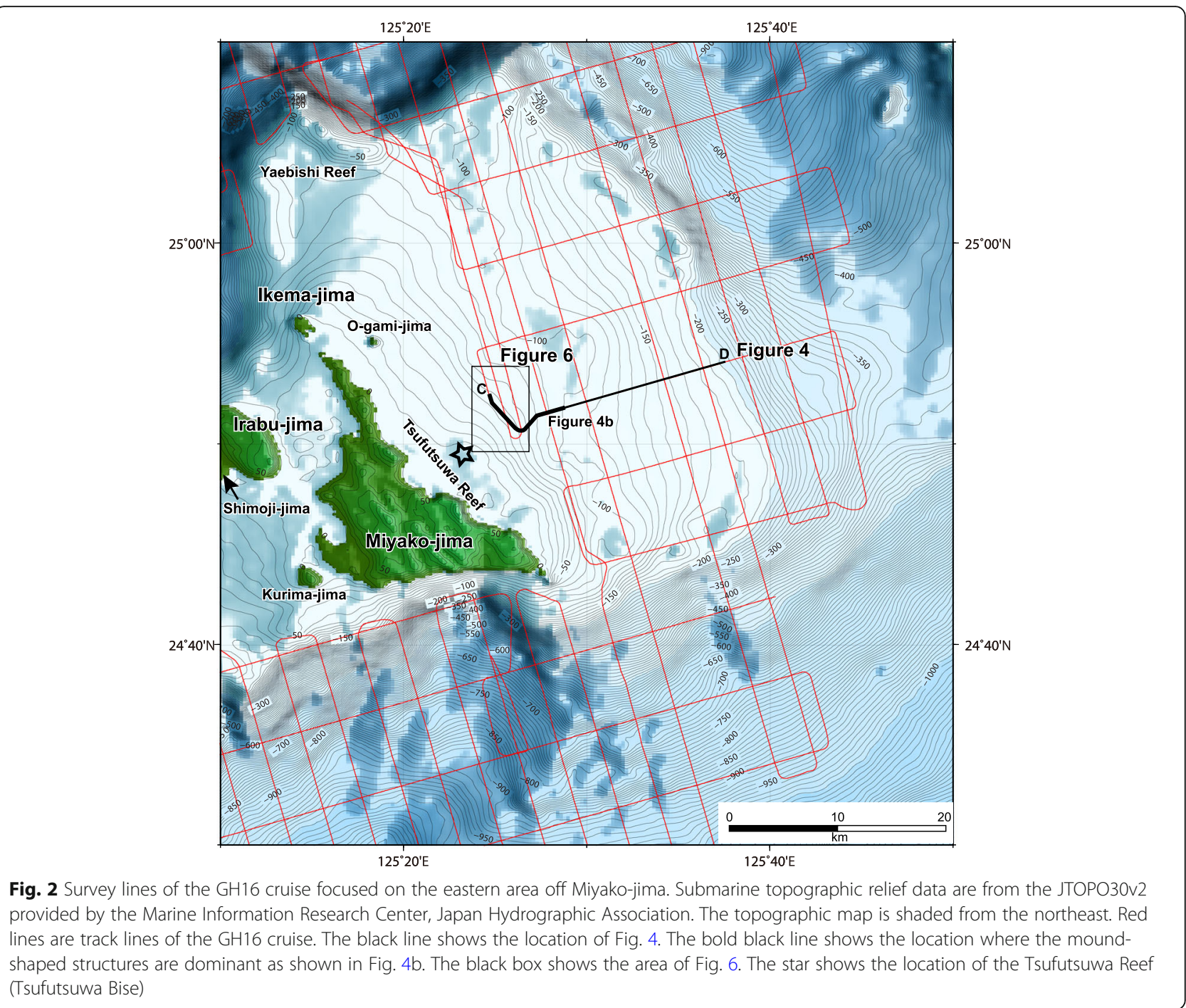

based on new geological data obtained via a mapping project conducted by the Geological Survey of Japan (GSJ) of the National Institute of Advanced Industrial Science and Technology (AIST) in waters around Miyako-jima during their 2016 cruise, the results of which have the potential to contribute to our understanding of coral reef formation and the response of coral reefs to postglacial sea-level rises in a coral reef province of a relatively high-latitude area.

\section{Geological setting}

The major islands of the Ryukyu Arc, which includes Miyako-jima, are considered to be forearc highs (Kizaki 1978; Letouzey and Kimura 1986). Along with the associated Ryukyu Trench, they are products of the subduction of the Philippine Sea Plate (PSP) beneath the Eurasian Plate. The PSP is subducting northwestward beneath the Eurasian Plate at a convergence rate of 4-9 cm/year (Seno et al. 1993), while the Okinawa Trough is a back-arc basin located beside the Ryukyu Arc that was formed in the late Miocene (Gungor et al. 2012) or the late Pliocene-early Pleistocene (Park et al. 1998; Shinjo 1999; Sibuet et al. 1998). The formation of the Okinawa Trough was a key geological event associated with complex tectonism and changes in the topographic configuration of the Ryukyu Arc. The Ryukyu Arc itself is divided into three regions (northern, central, and southern) by the Tokara Strait and the Kerama Gap (e.g., Konishi 1965). The stratigraphy on Miyako-jima and neighboring islets such as Irabu-jima, which are located in the southern Ryukyus, consists of the late Miocene-early Pleistocene Shimajiri Group and the Pleistocene Ryukyu Group (Kizaki 1985; Iryu et al. 2006). The Shimajiri Group on Miyako-jima consists of limited mudstone and sandstone outcrops located primarily on the eastern coast (Ujiié and Oki 1974). This group is considered to be a slope towards the 


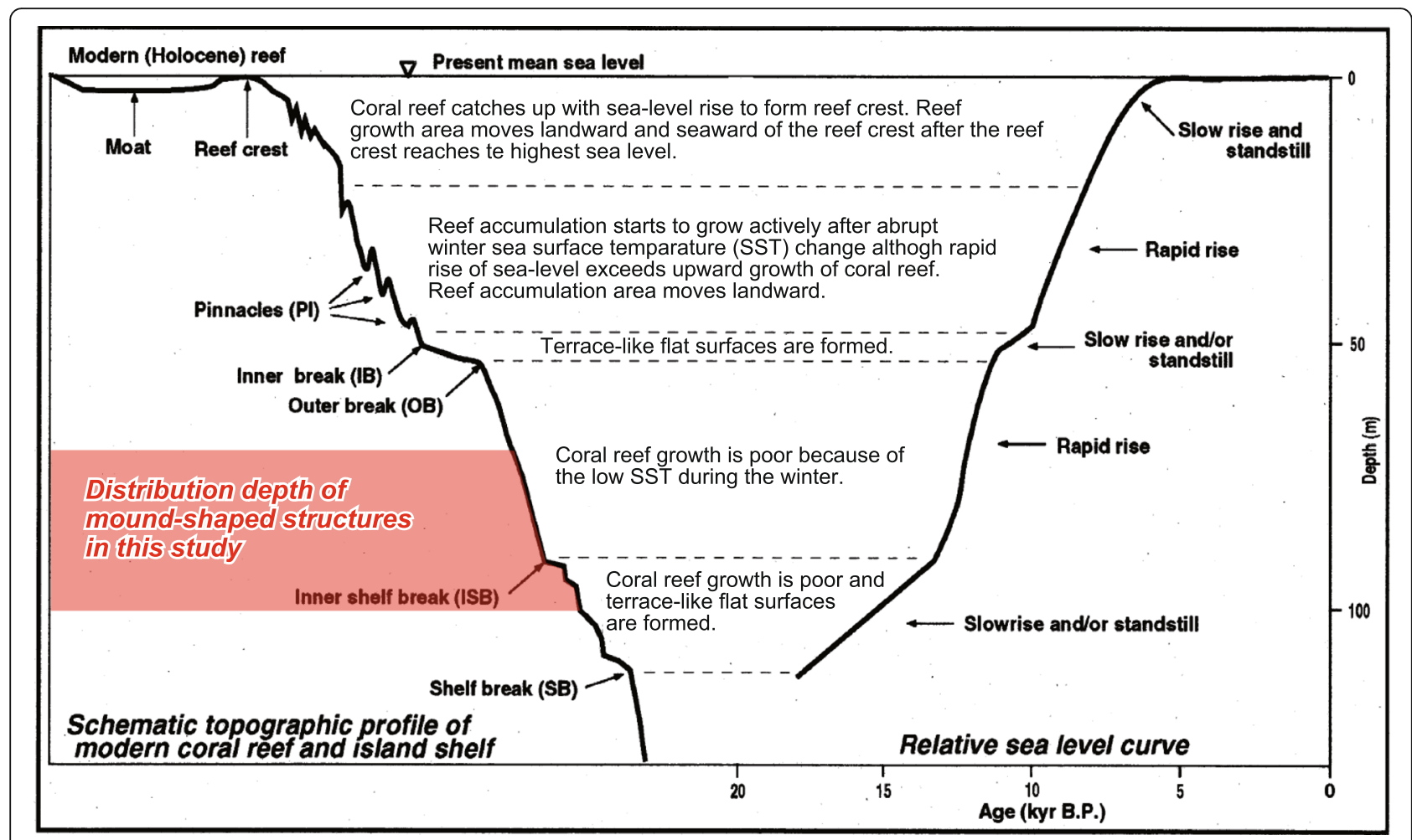

Fig. 3 Distribution depth of mound-shaped structures in this study and schematic geomorphic development of the island shelf after the Last Glacial Maximum in the central and southern Ryukyus (Hori and Kayanne 2000). This figure is modified from Hori and Kayanne (2000)

forearc basin deposit. Miyako-jima and Irabu-jima are mostly covered with Pleistocene carbonates formed in coral reefs and their associated shelves (Ryukyu Group) (Nakamori 1986; Sagawa et al. 2001; Humblet and Iryu 2014).

\section{Methods}

A GSJ research cruise (GH16) was conducted around Miyako-jima from July 28 to August 7, 2016, aboard the research vessel $(\mathrm{R} / \mathrm{V})$ Hakurei, operated by the Japan Oil, Gas and Metals National Corporation (JOGMEC). During this geological mapping project, we focused on water depths of more than $50 \mathrm{~m}$ and acquired more than 1878 nautical miles of highresolution multichannel seismic (MCS) profile data. Ship speeds during the cruise were maintained at approximately 9 knots, and bathymetric mapping and SBP survey measurements around Miyako-jima were conducted simultaneously on the same survey line as the MCS measurements. The SBP survey was conducted with a Parasound P70 unit (Atlas Hydrographics), which utilizes a parametric effect to generate a secondary low frequency signal (SLF) by emitting two primary higher frequencies signals (PHF). The PHF and SLF frequencies can be adjusted within $18-33$ and $0.5-6 \mathrm{kHz}$, respectively. SBP surveys show only two-dimensional images under the seabottom, so we confirmed the mound-shaped structures using bathymetric images. Bathymetric imaging was performed with an EM122 (in deep water) or EM 710 (in shallow water) multibeam echo sounder (MBES of Kongsberg). Our data are from the EM710 only, because the study area is shallower than $200 \mathrm{~m}$ deep. The EM710 operated at sonar frequencies in the 70 to $100 \mathrm{kHz}$ range for high-resolution seabed mapping in the study area.

\section{Results}

\subsection{SBP surveys}

SBP profiles show the characteristics of the sediments below the seafloor. Inoue et al. (2017) classified five acoustic facies distributed around Miyako-jima based on the patterns of their SBP features. Two of these facies' types, as classified by Inoue et al. (2017), appear in our study area (Fig. 4). In this paper, facies recognized in this area are simply described as Facies 1 and Facies 2. Facies 1 is characterized by a distinct, irregularly undulating strong reflector observed at the top of the sediments, but with unclear inner reflectors and/or chaotic patterns. In contrast, Facies 2 is characterized by a distinct, flat seafloor surface with a well-stratified internal reflector. In the SBP profile along transect C-D in Fig. 4a, several 

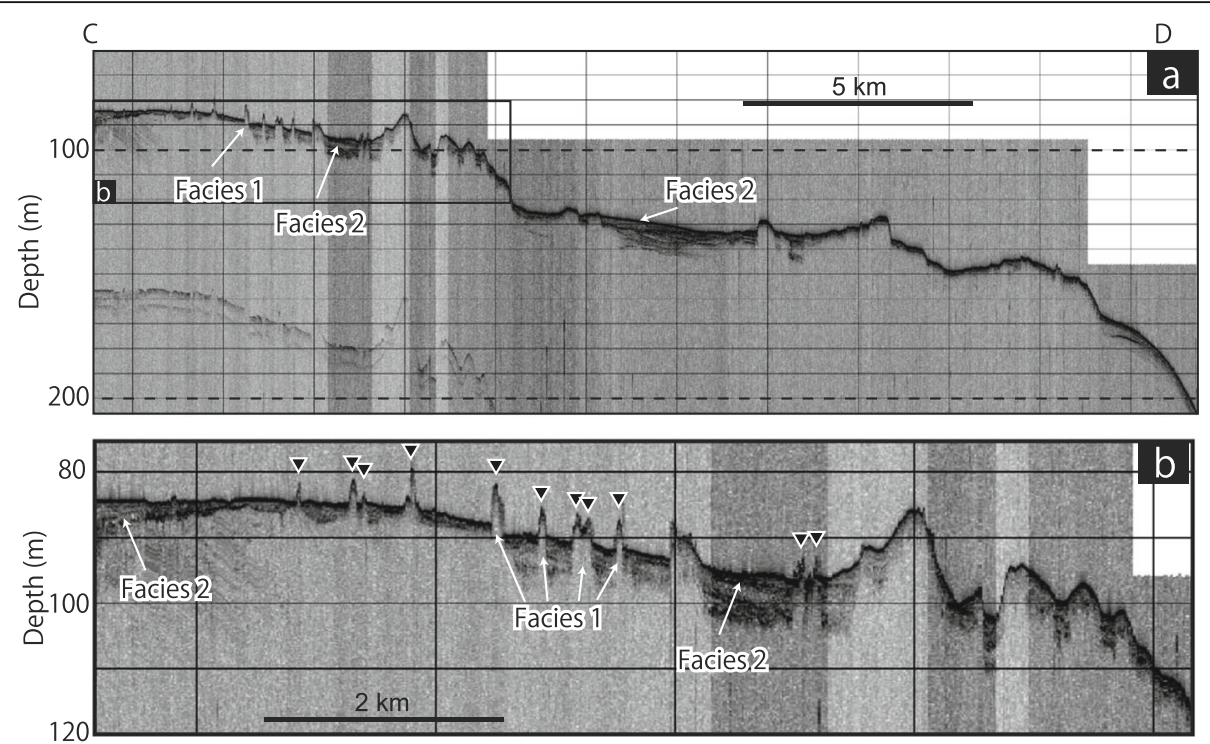

Fig. 4 SBP profiles off the eastern side of Miyako-jima (see Fig. 2 for the track location). This profile shows clear images of the mound-shaped structures. Inverted triangles indicate the mound-shaped structures

steep mounds about $50-100 \mathrm{~m}$ wide and $3-8 \mathrm{~m}$ high are recognized on the western part of the section. On the eastern part of the section, there is a relatively wide mound with a gentle slope. We focused on the relatively steep mounds distributed in the west. The SBP profile close-ups shown in Fig. 5 display small mounds that are outlined by strong reflections and onlapped by thin layers of stratified sediments (Facies 2). The covering sediments are approximately $3-5 \mathrm{~m}$ thick, and the maximum height of the mounds is $8 \mathrm{~m}$ above the sea floor. It should be noted that the mounds are found in water depths of 70-100 m. Our geological mapping had a survey line like that in Arai et al. (2018a) that was dense enough to observe the outline surrounding Miyako-jima.

\subsection{Bathymetric survey}

The topography around Miyako-jima is characterized by a relatively flat seafloor shallower than $200 \mathrm{~m}$ along the southern Ryukyus continuing from east-northeast to west-southwest and a significantly deeper topography extending across it in a north-northwest to southsoutheast direction. The outer edge of the flat seafloor off eastern Miyako-jima is at a water depth of approximately $200 \mathrm{~m}$ and drops steeply into the Miyako Saddle on its eastern side (Fig. 2). Patch reefs, grouped patch reefs, and table and platform reefs have been recognized around Miyako-jima (Coral Reefs of Japan 2004), but the resolution of our MBES topographic survey was not sufficient to classify all these reef types. There are a limited number of mound-shaped structures in the northeastern area off the Tsufutsuwa Reef (Tsufutsuwa Bise). A cross- sectional view (Fig. 6b, c) clearly shows several mounds scattered on the relatively flat seafloor.

\section{Discussion}

\subsection{Mound-shaped structures}

The SBP profiles and bathymetric map (Fig. 6) show mounds at water depths of $70-100 \mathrm{~m}$ off eastern Miyako-jima. The mound distribution found in this area is limited to the eastern side of the island. In this paper, we defined the mound-shaped structures as transparent mounds rising from the base of the surface sediment with internal reflectors. The mounds are about $100 \mathrm{~m}$ wide and about $3 \mathrm{~m}$ or more in height. The mounds' depths obtained in these surveys have gaps of several meters due to differences in measurement methods and correction data, but their relative width and height are very similar. The mound tops reached a maximum of 8 $\mathrm{m}$ above the seafloor. Sugisaki et al. (2019) reported that coarse- to medium-grained modern carbonate sediments are widely distributed throughout the area and that they collected coarse bioclastic sand and algae-covered carbonate block samples from the mounds using a grab sampler during the GK18-1 cruise. These results are consistent with Facies 1 and 2 in our SBP profiles. The mound surfaces were well indurated, and only algal carbonate blocks that encrusted the well-indurated surface were recovered in pictures taken by a submarine camera mounted on the grab sampler.

The mound-shaped structures' strong reflectivity on the surface, indicating a hard bottom, (Facies 1) may suggest the presence of erupted rocks such as submarine volcanoes, limestone of remnant mounds (karst 

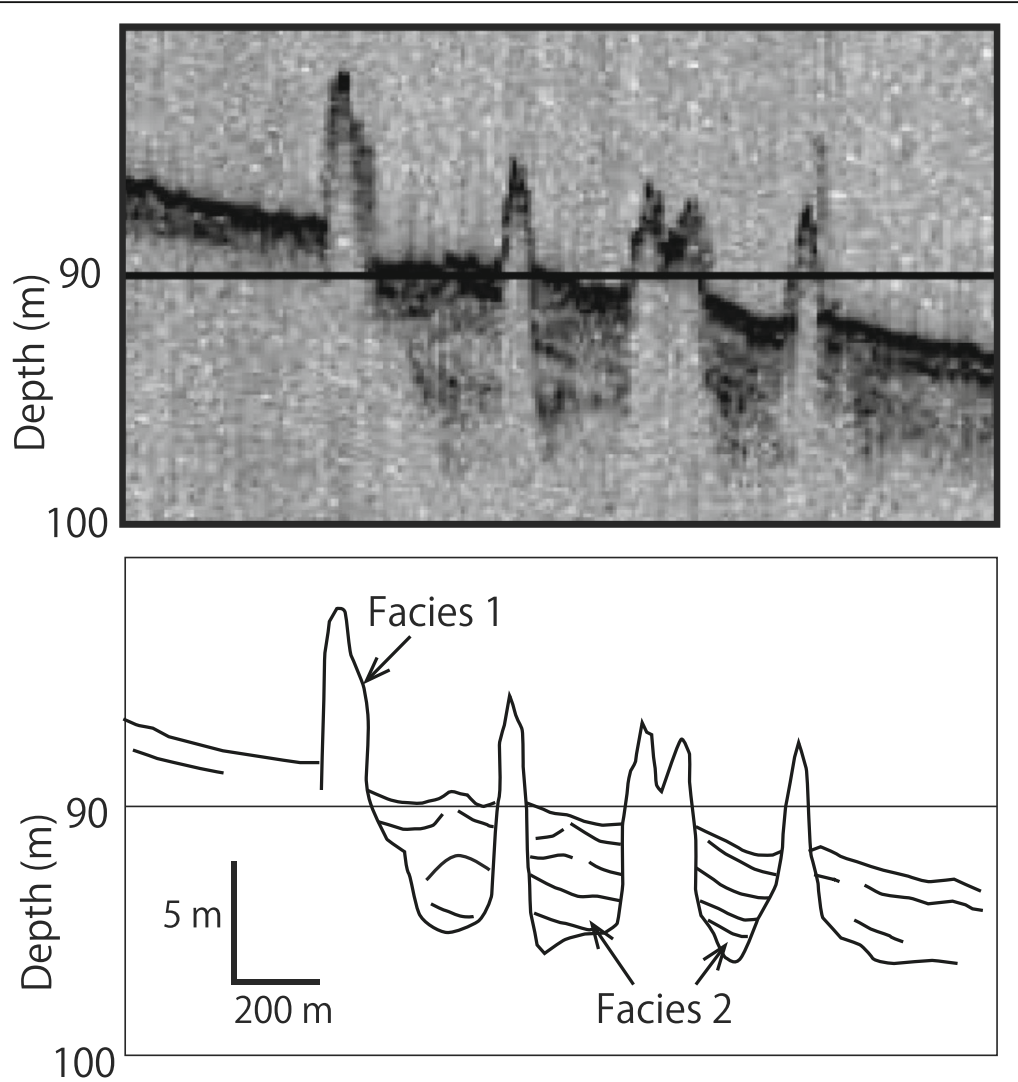

Fig. 5 SBP profile and corresponding schematic diagram showing the relationship between Facies 1 and Facies 2

landforms), or submerged reefs in the study area. Sato (2017) reported that no gravity or magnetic anomalies were distributed around the mound-shaped structures. These results indicate that the mound-shaped structures are not made of volcanic rocks and basement rock, which would be accompanied by magnetic and gravity anomalies, but rather should be considered to be made of well-indurated sedimentary rocks. We cannot state decisively that the mound-shaped structures are submerged reefs or limestone such as remnant mounds (karst landforms) at this time and subsurface sampling, such as drilling, will be required to clarify the origin of the mound-shaped structures. However, the sizes and shapes of the mound-shaped structures in the SBP profile images are topographically similar to those of pinnacles observed above the inner break of the island shelf off the central and southern Ryukyu Island Arc (Hori and Kayanne 2000; Fig. 3), although the depths of their distribution differ from those in Hori and Kayanne (2000).

Similar mound-shaped structures having acoustically chaotic properties under the seafloor were reported on the shelf off Irabu-Jima, which is located west of Miyako-jima (Obata and Tsuji 1992). Sasaki et al. (2006) dated samples collected from an isolated mound-shaped structure and confirmed that it was a lowstand coral reef. The lowstand coral reef interpreted from a seismic reflection survey by Obata and Tsuji (1992) and dated by Sasaki et al. (2006) is a mound buried under the seafloor. It is a little larger than the mounds observed in this study area. However, the difference in size is possibly due to the resolution of the equipment used to recognize the subsurface geology, and we consider the mounds to be of similar sizes at the resolution of the seismic profiling survey, with widths on the order of several hundred meters and heights on the order of $10 \mathrm{~m}$. The mound-shaped structures are on a similar scale in size and shape to submerged reefs (about $15 \mathrm{~m}$ in height: Arai et al. 2012) in the Last Glacial Maximum known around the study area. Consequently, we conclude that such mound-shaped structures in this study are possibly submerged coral reefs and reefal carbonate rocks that developed in the Last Glacial Period. Since the Last Glacial Maximum, the sea level has risen in a non-linear manner (Fairbanks 1989). The depth (70-100 m) of the tops of the mound-shaped structures matched periods of slow to rapid sea-level rise (Hori and Kayanne 2000; Fig. 4a), which could point to the mounds having grown during a period of slow sea-level rise and having been drowned during a period of rapid rise. In such cases, reef 

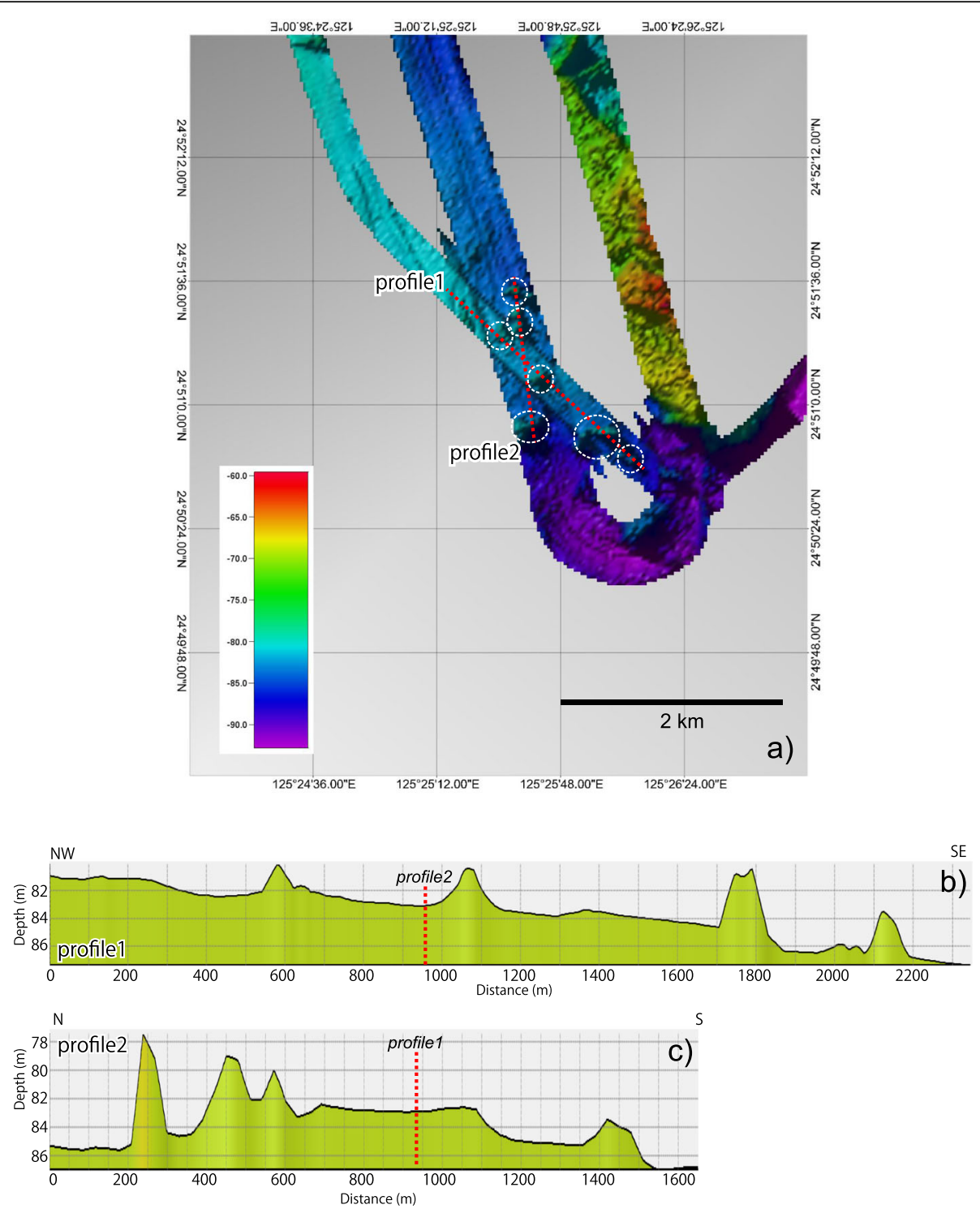

Fig. 6 MBES topography off eastern Miyako-jima. The red lines on the map show the cross-section locations. a Submarine topographic relief data obtained by MBES. Broken red lines indicate the location of profiles $(\mathbf{b}, \mathbf{c})$. The broken white circles indicate the mound-shaped structures. $\mathbf{b}$ Profile 1: NW-SE topographic profile. c Profile 2: N-S topographic profile

back-stepping and the ages of drowned reefs can be interpreted as successive cycles of reef-growth and drowning in low latitude areas of the world (Blanchon and Shaw, 1995; Khanna et al. 2017; Rovere et al. 2018). In considering the mound-shaped structures around Miyako-jima, it seems possible that reefs developed during the Last Glacial Period, then drowned due to sealevel rise outpacing reef growth.

Webster et al. (2018) reported the reverse of this process, where seaward migration of coral reefs in the Great Barrier Reef was caused by a rapid sea-level fall during the Last Glacial Maximum. In addition, Fujita et al. (2019) reported that the development of fringing reefs with shallow back-reef lagoons and the timing of reef-flat and back-reef formation is consistent with the two stepwise falls in sea level during the Last Glacial Maximum. In the SBP profiles of this survey area, the bases of the mound-shaped structures are found shallower than $100 \mathrm{~m}$ deep, and strong reflection surfaces that indicate a hard and uneven bottom are recognized continuously with the surfaces of the mound-shaped structures. In this study, we cannot confirm the base of mound-shaped structures; we recognized the base (maximum depth) of surface of mounds is about $100 \mathrm{~m}$. It is possible that the mound-shaped structures and the related reef were formed before the Last Glacial Maximum and then a hard, sub-exposed bottom surfaced due to sea-level fall during the Last Glacial Maximum. 
Subsequently, stratified deposits after the Last Glacial Maximum overlay the mounds. The Pleistocene limestone karst forming similar topography eroded during subaerial exposure, but we can conclude that at least carbonate rocks exist at this depth. However, since we do not have a sample at present, we cannot say definitively that these are reefs that developed during the sealevel fall. It will be necessary to collect samples in order to discuss their formation age and mechanism.

\subsection{Developments east of the Miyako-jima reef}

The mound-shaped structures examined in this study are very similar to those located off southern Okinawajima (Arai et al. 2012), although the base of the mounds off southern Okinawa formed at a water depth of $140 \mathrm{~m}$, which is deeper than that found in this study, thus indicating the possibility of tectonic subsidence in the southern Okinawa-jima region. Here, southern Okinawa-jima is subducting, related to the subduction of the Kerama gap (Arai et al. 2018b). In the survey area around Miyako-jima, on the other hand, the environment, in terms of tectonic movement, is considered to be relatively more stable than around southern Okinawa-jima. We consider the tectonically stable condition of the study area and the depth of the mound-shaped structures as being indicative of this structure having basically formed in the Last Glacial Maximum, possibly with aerial exposure off Miyako-jima.

The mound-shaped structures found in this survey are distributed in a limited area only offshore to the east of Miyako-jima. Recent coral reefs around Miyako-jima also develop commonly in the eastern part. In addition, Coral Reefs of Japan (2004) reported that recent corals are distributed in the eastern and northern areas off Miyako-jima. The eastern and northern areas have gentle slopes and shelves more than $20 \mathrm{~km}$ wide. On the other hand, the shelf off the southern slope of Miyakojima is about $2 \mathrm{~km}$ wide and is steeper than the eastern and northern slopes (Fig. 2). The mound-shaped structures examined in our study are submerged coral reefs or reefal carbonate rock located only $5 \mathrm{~km}$ northeast of the modern Tsufutsuwa Reef. That reef, which is $6-7$ $\mathrm{km}$ away from Miyako-jima, is about $0.8 \mathrm{~km}$ wide by 2.5 $\mathrm{km}$ long and extends northwest-southeast (Coral Reefs of Japan 2004). The bathymetric contours from the modern Tsufutsuwa Reef to the area where the moundshaped structures are located show continuous deepening toward the northeast (Fig. 2), and it is possible that the modern reefs have grown and migrated continuously since the deglaciation period. The migration of the reefs' position may have been caused by reef growth attempting to keep pace with the rising sea level during the early stages of deglaciation in the area of the mound-shaped structures.
We infer that the consolidated hard substrate of the mound-shaped structures influenced the development of the modern coral reef during deglaciation and shown that such back-stepping indicates sea-level rises. In the future, it will be necessary to conduct additional SBP and bathymetric mapping investigations in the study area, including the region around Tsufutsuwa Reef, using small boats because conventional research vessels are too large to operate in such shallow nearshore areas. The water at the base of the mounds was $100 \mathrm{~m}$ deep, and the top of the mounds was approximately $70-100 \mathrm{~m}$ deep (Figs. 3 and 4). The position and depth of the mound-shaped structures show affected active reef growth and the resultant reef movement's sensitivity to glacial sea-level changes in the Central and Southern Ryukyu Islands. Although we have no absolute chronology for the appearance of these mound-shaped structures, their depths indicate that coral reef development began and finished during sea-level fluctuations during the Last Glacial Maximum. If reef growth or drownings are indicators of rapid sea-level rises or falls, we believe that similarities in the structure and the top and bottom depths of such mounds can be used to provide a new approach to investigating local tectonics. With that in mind, additional research on this study area, including direct sampling using techniques such as submarine drilling, is required.

\section{Conclusions}

SBP surveys and bathymetric mapping have revealed the presence of mound-shaped structures $50-120 \mathrm{~m}$ wide and 3-8 $\mathrm{m}$ high, at water depths of $70-100 \mathrm{~m}$ in a limited area about $5 \mathrm{~km}$ northeast off the modern Tsufutsuwa Reef. The location of these newly discovered mound-shaped structures is believed to indicate backstepping of a reef growth area from the lowstand stage including the last deglaciation period. Accordingly, we conclude that reef growth in the area of the moundshaped structures on the Miyako-jima island shelf most likely kept pace with sea-level rises that would have occurred during the deglaciation period based on comparison with other reefal areas. Additionally, since reef growth and drownings can be seen as indicators of rapid sea-level change, and since back-stepping appears to have occurred as the living reef abruptly moved towards the southwest, we feel that there is a need for further studies and research in the study area that include direct sampling in order to clarify the origin of the moundshaped structures in this study and the sea-level and environmental changes in the Ryukyu area as a subtropical area.

\section{Abbreviations}

AIST: National Institute of Advanced Industrial Science and Technology; GSJ: Geological Survey of Japan; IGG: Research Institute of Geology and 
Geoinformation; JOGMEC: Japan Oil, Gas and Metals National Corporation; PSP: Philippine Sea Plate; SBP: Sub-bottom profiling; PHF: Primary high frequency; SLF: Secondary low frequency; MBES: Multibeam echo sounding

\section{Acknowledgements}

This study was carried out as a part of the "Geological Mapping Project Around the Okinawa Islands" by the Geological Survey of Japan (GSJ) of the National Institute of Advanced Industrial Science and Technology (AIST). We are grateful to Captain Toshiro Fukumoto and the crew of the RN Hakurei for the professionalism they displayed during the cruise. We are also indebted to the other scientific members of the GH16 cruise. In addition, we are deeply indebted to Y. Iryu for his editorial work and to the two anonymous reviewers whose constructive comments and suggestions have improved our manuscript.

\section{Authors' contributions}

TI proposed the topic and conceived and designed the study. KA contributed to the interpretation. Both authors read and approved the final manuscript.

\section{Authors' information}

TI is a senior researcher in the Marine Geology Research Group in the Research Institute of Geology and Geoinformation (IGG), the Geological Survey of Japan (GSJ) of the National Institute of Advanced Industrial Science and Technology (AIST), and is an expert on seismic reflection surveys. KA is the Deputy Director of the IGG, GSJ, AIST. Both authors are members of the "Geological Mapping Project Around the Okinawa Islands".

\section{Funding}

This work was carried out as a part of the "Geological Mapping Project Around the Okinawa Islands" by the GSJ-AIST.

\section{Availability of data and materials}

Please contact author for data requests.

\section{Competing interests}

The authors declare that they have no competing interest.

\section{Received: 6 April 2020 Accepted: 19 August 2020}

\section{Published online: 21 September 2020}

\section{References}

Arai K, Inoue T, Sato T (2018a) High-density surveys conducted to reveal active deformations of the upper forearc slope along the Ryukyu Trench, western Pacific, Japan. Prog Earth Planetary Sci 5:45 https://doi.org/10.1186/s40645018-0199-0

Arai K, Inoue T, Sato T (2018b) Marine geology map of the vicinity of southern Okinawa-Jima Island. Marine Geology Map Series, no. 90(CD). Geological Survey of Japan (in Japanese)

Arai K, Matsuda H, Sasaki K, Machiyama H, Yamaguchi T, Inoue T, Sato T, Takayanagi H, Iryu Y (2016) A newly discovered submerged reef on the Miyako-Sone platform, Ryukyu Island Arc, Northwestern Pacific. Mar Geol 373: 49-54 https://doi.org/10.1016/j.margeo.2016.01.007

Arai K, Sato T, Inoue T (2012) Seismic profiling survey of submerged coral reefs near Okinawa Island. Proc. $12^{\text {th }}$ Int Coral Reef Symp. 1B Reef response to sealevel and environmental changes

Bard E, Hamelin B, Arnold M, Montaggioni L, Cabioch G, Faure G, Rougerie F (1996) Deglacial sea-level record from Tahiti corals and the timing of global meltwater discharge. Nature 382:241-244

Blanchon P, Shaw J (1995) Reef-drowning during the last deglaciation: evidence for catastrophic sea-level rise and ice-sheet collapse. Geology 23:4-8

Camoin GF, Cabioch G, Eisenhauer A, Braga JC, Hamelin B, Lericolais G (2006) Environmental significance of microbialites in reef environments during the last deglaciation. Sediment Geol 185:277-295

Collins LB, Testa V, Zhao J, Qu D (2011) Holocene growth history and evolution of the Scott Reef carbonate platform and coral reef. J R Soc West Aust 94: 239-250

Coral Reefs of Japan (2004) The Japanese Coral Reef Society and Ministry of the Environment (Eds.).
Deschamps P, Durand N, Bard E, Hamelin B, Camoin G, Thomas AL, Henderson GM, Okuno J, Yokoyama Y (2012) Ice-sheet collapse and sea-level rise at the Bølling warming 14,600 years ago. Nature 483:559-564

Edwards RL, Beck JW, Burr GS, Donahue DJ, Chappell JMA, Bloom AL, Druffel ERM, Taylor FW (1993) A large drop in atmospheric ${ }^{14} \mathrm{C} /{ }^{12} \mathrm{C}$ and reduced melting in the Younger Dryas, documented with ${ }^{230} \mathrm{Th}$ ages of corals. Science 260:962-968

Fairbanks RG (1989) A 17,000-year glacio-eustatic sea-level record: influence of glacial melting rates on the Younger Dryas event and deep-ocean circulation. Nature 342:637-642

Fujita K, Yagioka N, Nakada C, Kan H, Miyairi Y, Yokoyama Y, Webster JM (2019) Reef-flat and back-reef development in the Great Barrier Reef caused by rapid sea-level fall during the Last Glacial Maximum (30-17 ka). Geology 48: 39-43 https://doi.org/10.1130/G46792.1

Fürstenau J, Lindhorst S, Betzler C, Hübscher C (2010) Submerged reef terraces of the Maldives (Indian Ocean). Geo-Mar Lett 30:511-515 https://doi.org/10. 1007/s00367-009-0174-2

Gungor A, Lee GH, Kim HJ, Han HC, Kang MH, Kim J, Sunwoo D (2012) Structural characteristics of the northern Okinawa Trough and adjacent areas from regional seismic reflection data: geologic and tectonic implications. Tectonophysics 522-523:198-207

Hori K, Kayanne H (2000) Submarine morphology of the island shelf off the Middle and South Ryukyu Islands, southwestern Japan. Geogr Rev Jpn 73A-3: 161-181 (in Japanese with English abstract)

Hori N (1977) A morphometrical study on the geographical distribution of coral reefs. Geogr Rep Tokyo Metrop Univ 12:1-75

Humblet M, Iryu Y (2014) Pleistocene coral assemblages on Irabu-jima, South Ryukyu Islands, Japan. Paleontological Res 18:224-244

Inoue T, Misawa A, Arai K (2017) Profiles by Sub-Bottom Profiler (SBP) around Miyako Shima Island in GH16 cruise. GSJ Interim Rep 72:34-46 (in Japanese)

Iryu Y, Matsuda H, Machiyama H, Piller WE, Quinn TM, Mutti M (2006) An introductory perspective on the COREF Project. Island Arc 15:393-406

Khanna P, Droxler AW, Nittrouer JA, Tunnell JW Jr, Shirley TC (2017) Coralgal reef morphology records punctuated sea-level rise during the last deglaciation. Nat Commun 8:1046 https://doi.org/10.1038/s41467-017-00966-X

Kizaki K (1978) Tectonics of the Ryukyu Island. Arc J Phys Earth 26(Suppl):S301S307

Kizaki K (1985) Kizaki (Ed.), Geology of the Ryukyu Island Arc, Okinawa Times, Naha (in Japanese)

Konishi K (1965) Geotectonic framework of the Ryukyu Islands (Nansei-shoto). $J$ Geol Soc Jpn 71:437-457 (in Japanese with English abstract)

Letouzey J, Kimura M (1986) The Okinawa Trough: genesis of a back-arc basin developing along a continental margin. Tectonophysics 125:209-230

Matsuda H, Arai K, Machiyama H, Iryu Y, Tsuji Y (2011) Submerged reefal deposits near a present-day northern limit of coral reef formation in the northern Ryukyu Island Arc, northwestern Pacific Ocean. Island Arc 20:411-425

Nakamori T (1986) Community structures of recent and Pleistocene hermatypic corals in the Ryukyu Islands, Japan. Science Report of the Tohoku University, 2nd Series. Geology 56:71-133

Obata M, Tsuji Y (1992) Quaternary geohistory inferred by seismic stratigraphy of a carbonate province in an active margin, off Miyako Island, south Ryukyus, Japan. Carbonates Evaporites 7:150-165

Park JO, Tokuyama H, Shinohara M, Suyehiro K, Taira A (1998) Seismic record of tectonic evolution and backarc rifting in the southern Ryukyu island arc system. Tectonophysics 294:21-42

Peltier WR, Fairbanks RG (2006) Global glacial ice volume and last glacial maximum duration from an extended Barbados sea level record. Quat Sci Rev 25:3322-3337

Rovere A, Khanna P, Bianchi CN, Droxler AW, Morri C, Naar DF (2018) Submerged reef terraces in the Maldivian Archipelago (Indian Ocean). Geomorphology 317:218-232

Sagawa N, Nakamori T, Iryu Y (2001) Pleistocene reef development in the southwest Ryukyu Islands, Japan. Paleoceanography Paleoclimatology Paleoecology 175:302-323

Sasaki K, Omura A, Miwa A, Tsuji Y, Matsuda H, Nakamori T, Iryu Y, Yamada T, Sato Y, Nakagawa H (2006) 230Th/234 U and 14C dating of a lowstand coral reef beneath the insular shelf off Irabu Island, Ryukyus, southwestern Japan. Island Arc 15:455-467

Sato M (2017) Preliminary results of the gravity and magnetic anomaly survey during the GH16 cruise area (around Miyako Shima Islands). GSJ Interim Rep 72:23-33 (in Japanese) 
Seno T, Stein S, Gripp AE (1993) A model for the motion of the Philippine Sea Plate consistent with NUVEL-1 and geological data. J Geophys Res 89:17941-17948

Shinjo R (1999) Geochemistry of high Mg andesites and the tectonic evolution of the Okinawa Trough-Ryukyu arc system. Chem Geol 157:69-88

Sibuet JC, Deffontaines B, Hsu SK, Thareau N, Le Formal JP, Liu CS, Party A (1998)

Okinawa Trough backarc basin: early tectonic and magnetic evolution. J Geophys Res 103(B12):30245-30267

Sugisaki S, Itaki T, Katayama H, Ajioka T, Tokuda Y (2019) Bottom sediments distribution around Miyako, Ishigaki, Iriomote Islands. GSJ Interim Rep 77 71-80 (in Japanese)

Ujiié H, Oki K (1974) Uppermost Miocene-lower Pleistocene planktonic foraminifera from the Shimajiri Group of Miyako-jima, Ryukyu Islands. Mem Natl Sci Mus Tokyo 7:31-52

Webster JM, Braga JC, Humblet M, Potts DC, Iryu Y, Yokoyama Y, Fujita K, Bourillot R, Esat TM, Fallon S, Thompson WG, Thomas AL, Kan H, McGregor HV, Hinestrosa G, Obrochta SP, Lougheed BC (2018) Response of the Great Barrier Reef to sea-level and environmental changes over the past 30,000 years. Nat Geosci 11:426-432 https://doi.org/10.1038/s41561-018-0127-3

Webster JM, Clague DA, Riker-Coleman K, Gallup C, Braga JC, Potts D, Moore JG, Winterer EL, Paull CK (2004) Drowning of the -150 m reef off Hawaii: a casualty of global meltwater pulse 1A? Geology 32:249-252

Yokoyama Y, Esat TM, Thompson WG, Thomas AL, Webster JM, Miyairi Y, Sawada C, Aze T, Matsuzaki H, Okuno J, Fallon S, Braga JC, Humblet M, Iryu Y, Potts DC, Fujita K, Suzuki A, Kan H (2018) Rapid glaciation and a two-step sea level plunge into the Last Glacial Maximum. Nature 559:603-607 https://doi.org/ 10.1038/s41586-018-0335-4

\section{Publisher's Note}

Springer Nature remains neutral with regard to jurisdictional claims in published maps and institutional affiliations.

\section{Submit your manuscript to a SpringerOpen ${ }^{\circ}$ journal and benefit from:}

- Convenient online submission

- Rigorous peer review

- Open access: articles freely available online

- High visibility within the field

- Retaining the copyright to your article

Submit your next manuscript at $\boldsymbol{\nabla}$ springeropen.com 